\title{
A novel PUS7 mutation causes intellectual disability with autistic and aggressive behaviors
}

Hossein Darvish, PhD, Luis J. Azcona, BA, Elham Alehabib, MSc, Faezeh Jamali, MSc, Abbas Tafakhori, MD, Sakineh Ranji-Burachaloo, MD, Joanna C. Jen, MD, PhD, and Coro Paisán-Ruiz, PhD

Neurol Genet 2019;5:e356. doi:10.1212/NXG.0000000000000356

Recently, homozygous PUS7 mutations causing premature stop and truncation of the gene product were identified in 3 independent consanguineous families presenting with intellectual disability (ID), speech delay, short stature, microcephaly, and aggressive behavior. ${ }^{1}$ PUS7 encodes for a pseudouridine synthase 7 that catalyzes the isomerization of RNA uridine to RNA pseudouridine (Psi), which is the most abundant modified nucleotide found in all cellular RNAs and which may function as an RNA chaperone. The encoded protein contains a pseudouridine synthase domain of the TruD family that modifies uracil-13 in tRNA. Two homozygous mutations c.89_90del (p.Thr30Lysfs $\left.20^{*}\right)$ and c.1348C $>$ T (p.Arg450*) resulted in nonsensemediated mRNA decay, meaning that mRNA transcripts containing the premature stop codons were eliminated through surveillance mechanisms, while the third mutation, consisting of a homozygous deletion encompassing the penultimate exon 15, escaped the nonsensemediated mRNA decay to encode a mutant protein missing the $\mathrm{C}$ terminus including the TruD catalytic domain. All identified PUS7 variants resulted in aberrant pseudouridylation of at least 10 cytosolic tRNAs at position $13 .{ }^{1}$

\section{Clinical and scientific findings}

We report a novel PUS7 homozygous mutation resulting in p.Gly128Arg amino-acid translation in a consanguineous Afghani family presenting with similar but milder clinical features without microcephaly and short stature (table e-1, links.lww.com/NXG/A180), further confirming the pathogenic role of PUS7 in ID syndromes with autistic features, speech delays, and aggressive behaviors.

The entire nuclear family of 2 healthy parents and 2 affected siblings (figure) was subjected to homozygosity mapping (HM) using high-throughput single nucleotide polymorphism genotyping (HumanOmniExpress Exome arrays v1.3; Illumina Inc., San Diego, CA) as previously described. ${ }^{2,3}$ The generated single nucleotide polymorphism data were used to determine regions of homozygosity present exclusively in the affected siblings but not their healthy parents. A total of 10 different homozygous tracks were identified (table e-2, links.lww.com/NXG/A180). We then proceeded to perform whole genome sequencing (WGS) analyses in both affected siblings. WGS was carried out at the New York Genome Center and the data were analyzed as previously described. ${ }^{2,4}$ Based on parental consanguinity and recessive inheritance (figure), novel and rare genomic variations, including nonsynonymous, frame-shift, splice site, small insertions and deletions, as well as gain/loss of stop codons, present in homozygosity or compound heterozygosity were considered as potential candidates. All genetic variations present in the regions of homozygosity were prioritized. Ten out of 303 genomic variations found to be present in

\author{
Correspondence \\ Dr. Paisán-Ruiz \\ coro.paisan-ruiz@mssm.edu
}


Figure Identification of a PUS7 homozygous mutation in a family with intellectual disability (ID), autistic features, and aggressive behaviors

A
\begin{tabular}{|cccccccc|}
\hline Chr & Position & Gene (exon) & Nucleotide change & Protein change & Reference transcript & GNOMAD & CADD \\
\hline 7 & $94,037,520$ & COL1A2 (exon 14) & c.665G>A & p.Arg222Lys & NM_000089 & N.A & 25.7 \\
7 & $101,188,732$ & COL26A1 (exon 7) & c.817G>C & p.Gly273Arg & NM_001278563 & N.A & 15.73 \\
7 & $105,148,578$ & PUS7 (exon 1) & c.382G>A & p.Gly128Arg & NM_001318163 & N.A & 23.3 \\
\hline
\end{tabular}

B

C

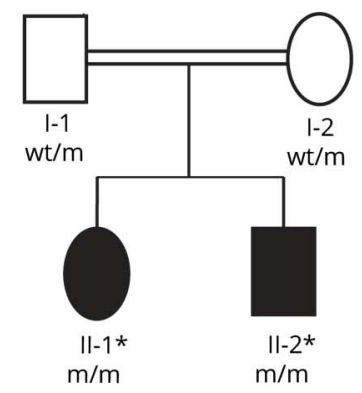

PUS7 mutation (p.Gly128Arg; c.382G>A)
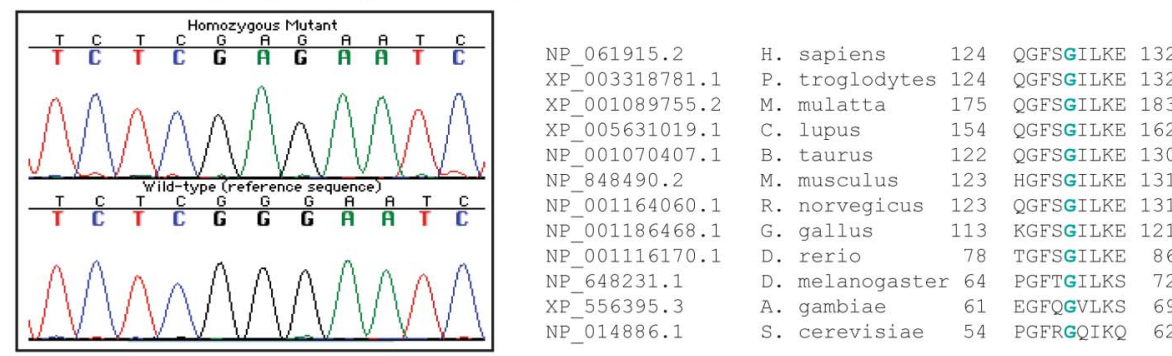

D

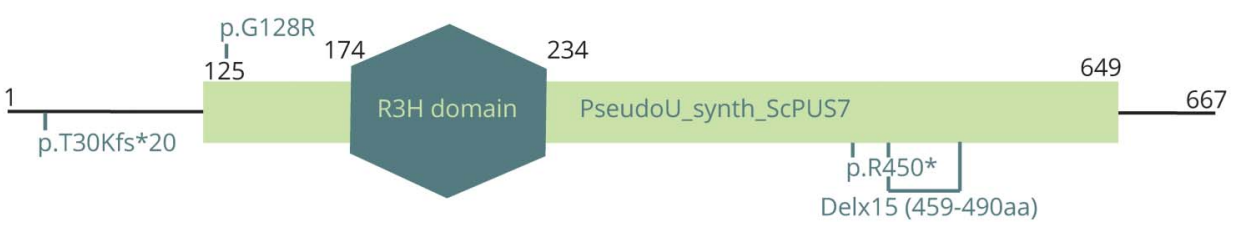

(A) Genomic variants identified in the genomes of 2 siblings with ID, autistic features, and aggressive behaviors. Disease-causing mutation is highlighted in bold. CADD = combined annotation dependent depletion (cadd.gs.washington.edu/); GNOMAD = genome aggregation database (gnomad.broadinstitute. org/); and NA = not applicable. Recessive mutations in COL1A2 cause Ehlers-Danlos syndrome. (B) Pedigree structure of the examined ID family. Wt/m indicates heterozygous carrier for the PUS7 p.Gly128Arg mutation while $\mathrm{m} / \mathrm{m}$ indicates homozygous carrier. Affected siblings are represented with a black square (male) and a black circle (female). *Indicates participants that underwent whole genome sequencing analyses. (C) Sanger chromatogram sequences of the PUS7 exon 1 containing the c.382G>A mutation are shown on the left, while G128 amino-acid conservation among other species is shown on the right. (D) PUS7 protein structure. R3H domain that is predicted to bind single-stranded DNA; PseudoU_synth_ScPUS7 is a pseudouridine synthase domain of the TruD family (PMID:12756329). The PUS7 mutation identified in this study is represented at the top while previously reported PUS7 mutations are represented at the bottom.

both affected siblings were homozygous; however, only 3 were located within the previously determined homozygous tracks (figure, table e-2). These 3 novel genetic variations were located within the COL1A2, COL26A1, and PUS7 genes, and none of them were present in public databases, including the Iranome browser (iranome.com/), the Greater Middle-East variome (igm.ucsd.edu/gme/), and the Genome Aggregation database (gnomAD; gnomad.broadinstitute.org/), and disease databases such as ClinVar (ncbi.nlm.nih.gov/clinvar/) and the Human Gene Mutation Database (hgmd.org).

Mutations in COL1A2 encoding collagen of skin, tendon, and bone are associated with diseases of the connective tissues distinct from the manifestations of our family and not observed in the patients. ${ }^{5}$ No human disease has been associated with mutations in COL26A1, which encodes a protein with collagen-like characteristics expressed in mouse mesenchyme of the head, skeletal muscles, and kidney (Mendelian Inheritance in Man [MIM] \#608927). Given the association of PUS1 (MIM \#600462) and PUS3 (MIM\#616283) genes with ID syndromes with speech and motor impairments, ${ }^{6,7}$ we favored the nucleotide variant in the PUS7 gene as a causative. The recent identification of 3 different ID families with pathogenic PUS7 mutations ${ }^{1}$ strengthened the likelihood of c.382G $>$ A (p.Gly128Arg) as the disease-causing mutation. The pathogenicity of this novel PUS7 mutation is further supported by its segregation with disease status (figure A-C), its location within a region of homozygosity identified through the performed HM analyses (table e-2, links.lww. com/NXG/A180), and the alteration of an evolutionarily conserved glycine down to yeast (figure, C). The PUS7 p.Gly128Arg mutation lies within the Pseudouridine synthase TruD domain (figure, D) such that this amino acid alteration may disrupt pseudouridylation, similar to the recently described truncation mutations.

We present genetic and clinical evidence of another family identified with ID, speech delay, motor impairments, and aggressive behavior due to pathogenic PUS7 mutations. The absence of highly extreme phenotypes such as short stature or microcephaly in this family might reflect genotypephenotype correlation, since this family presented with a PUS7 missense mutation that may be hypomorphic, while previously reported families carried nonsense or frameshift mutations that may cause loss of function. This is the first report of a PUS7 missense mutation that confirms PUS7 as 
a pathogenic gene for ID syndromes with speech impairments and aggressive behaviors.

\section{Acknowledgment}

The authors thank the patients and their relatives for their cooperation in this study.

\section{Study funding}

This work was supported by the Semnan University of Medical Sciences and the NINDS of the NIH (R01NS079388; C. Paisán-Ruiz).

\section{Disclosure}

Disclosures available: Neurology.org/NG.

\section{Publication history}

Received by Neurology: Genetics March 3, 2019. Accepted in final form June 24, 2019.

\section{References}

1. de Brouwer APM, Abou Jamra R, Kortel N, et al. Variants in PUS7 cause intellectual disability with speech delay, microcephaly, short stature, and aggressive behavior. Am J Hum Genet 2018;103:1045-1052.

2. Khodadadi H, Azcona LJ, Aghamollaii V, et al. PTRHD1 (C2orf79) mutations lead to autosomal-recessive intellectual disability and parkinsonism. Mov Disord 2017;32: 287-291.

3. Krebs CE, Karkheiran S, Powell JC, et al. The Sac1 domain of SYNJ1 identified mutated in a family with early-onset progressive Parkinsonism with generalized seizures. Hum Mutat 2013;34:1200-1207.

4. Taghavi S, Chaouni R, Tafakhori A, et al. A clinical and molecular genetic study of 50 families with autosomal recessive parkinsonism revealed known and novel gene mutations. Mol Neurobiol 2018;55:3477-3489.

5. Schwarze U, Hata R, McKusick VA, et al. Rare autosomal recessive cardiac valvular form of Ehlers-Danlos syndrome results from mutations in the COL1A2 gene that activate the nonsense-mediated RNA decay pathway. Am J Hum Genet 2004;74: 917-930.

6. Bykhovskaya Y, Casas K, Mengesha E, Inbal A, Fischel-Ghodsian N. Missense mutation in pseudouridine synthase 1 (PUS1) causes mitochondrial myopathy and sideroblastic anemia (MLASA). Am J Hum Genet 2004;74:1303-1308.

7. Shaheen R, Han L, Faqeih E, et al. A homozygous truncating mutation in PUS3 expands the role of tRNA modification in normal cognition. Hum Genet 2016;135: $707-713$. 


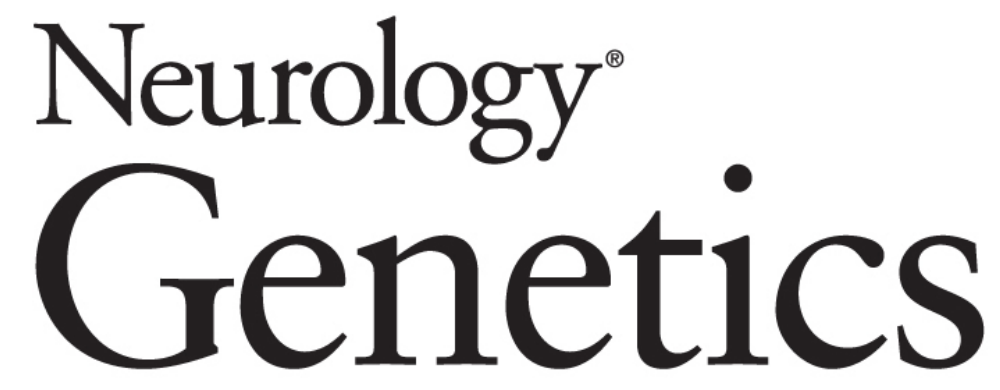

\section{A novel PUS7 mutation causes intellectual disability with autistic and aggressive behaviors}

Hossein Darvish, Luis J. Azcona, Elham Alehabib, et al. Neurol Genet 2019;5;

DOI 10.1212/NXG.0000000000000356

This information is current as of September 4, 2019

Neurol Genet is an official journal of the American Academy of Neurology. Published since April 2015, it is an open-access, online-only, continuous publication journal. Copyright Copyright () 2019 The Author(s). Published by Wolters Kluwer Health, Inc. on behalf of the American Academy of Neurology.. All rights reserved. Online ISSN: 2376-7839.

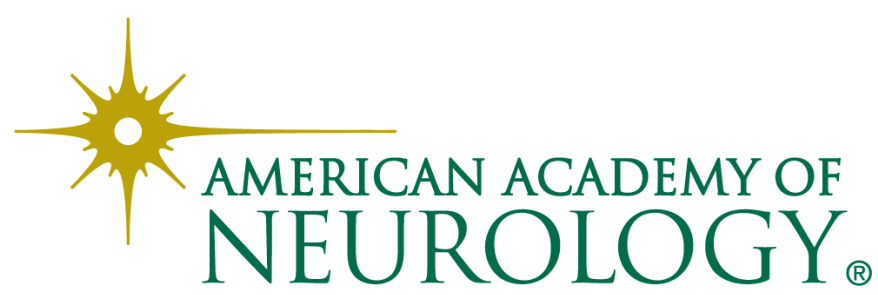




\section{Updated Information \& Services}

References

Citations

Subspecialty Collections

Permissions \& Licensing

Reprints including high resolution figures, can be found at:

http://ng.neurology.org/content/5/5/e356.full.html

This article cites 7 articles, 0 of which you can access for free at: http://ng.neurology.org/content/5/5/e356.full.html\#\#ref-list-1

This article has been cited by 1 HighWire-hosted articles: http://ng.neurology.org/content/5/5/e356.full.html\#\#otherarticles

This article, along with others on similar topics, appears in the following collection(s):

Association studies in genetics

http://ng.neurology.org//cgi/collection/association_studies_in_genetics Autism

http://ng.neurology.org//cgi/collection/autism

Developmental disorders

http://ng.neurology.org//cgi/collection/developmental_disorders

Genetic linkage

http://ng.neurology.org//cgi/collection/genetic_linkage

Mental retardation

http://ng.neurology.org//cgi/collection/mental_retardation

Information about reproducing this article in parts (figures,tables) or in its entirety can be found online at:

http://ng.neurology.org/misc/about.xhtml\#permissions

Information about ordering reprints can be found online:

http://ng.neurology.org/misc/addir.xhtml\#reprintsus

Neurol Genet is an official journal of the American Academy of Neurology. Published since April 2015, it is an open-access, online-only, continuous publication journal. Copyright Copyright () 2019 The Author(s). Published by Wolters Kluwer Health, Inc. on behalf of the American Academy of Neurology.. All rights reserved. Online ISSN: 2376-7839.

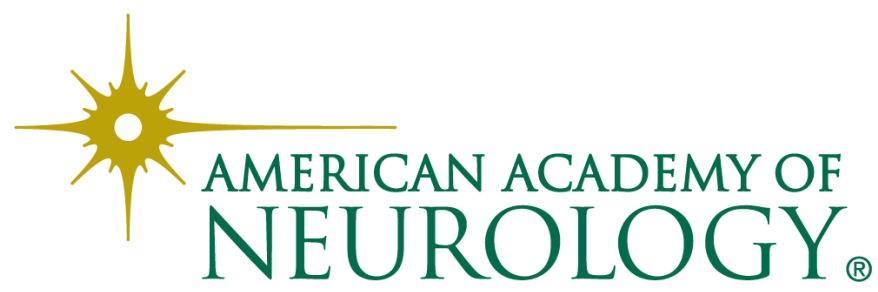

